\title{
The Moderating Role of Moral Obligation on the Relationship between Non -Economic Factors and Tax Evasion among SMEs: A Conceptual Framework
}

\author{
Nayef Mohammad Al-Rahamneh", Zainol Bin Bidin \\ Tunku PuteriIntan Safinaz School of Accountancy (TISSA-UUM), Universiti Utara Malaysia (UUM), Malaysia
}

Received October 19, 2021; Revised December 13, 2021; Accepted January 17, 2022

\section{Cite This Paper in the following Citation Styles}

(a): [1] Nayef Mohammad Al-Rahamneh, Zainol bin Bidin, "The Moderating Role of Moral Obligation on the Relationship between Non -Economic Factors and Tax Evasion among SMEs: A Conceptual Framework," Universal Journal of Accounting and Finance, Vol. 10, No. 2, pp. 425 - 432, 2022. DOI: 10.13189/ujaf.2022.100206.

(b): Nayef Mohammad Al-Rahamneh, Zainol bin Bidin (2022). The Moderating Role of Moral Obligation on the Relationship between Non -Economic Factors and Tax Evasion among SMEs: A Conceptual Framework. Universal Journal of Accounting and Finance, 10(2), 425 - 432. DOI: 10.13189/ujaf.2022.100206.

Copyright $\mathrm{C} 2022$ by authors, all rights reserved. Authors agree that this article remains permanently open access under the terms of the Creative Commons Attribution License 4.0 International License

\begin{abstract}
Globally, Tax evasion has always been a continual defiance to policy makers. A developing nation is primarily reliant on tax revenue and foreign aids to keep the country afloat. To provide sufficient tax revenue, efficient tax collection and competent tax administration are required. Understanding the determinants that influence tax evasion, and the proper solutions to address these factors, can help to reduce the negative repercussions of tax revenue loss in both developing and developed countries globally. This is a conceptual paper of a future study based on the survey of previous literatures, particularly the socio-psychological theories. Subsequently, this study debates that integrating non-Economics factors, namely Peer Influence, Tax Fairness and Tax Complexity, together could probably better demonstrate tax evasion determinants. Consequently, the goal of this research is to give a proposed conceptual framework for the role of moral obligation in moderating the relationship between peer influence, tax justice, tax complexity, and tax evasion among small and medium enterprises (SMEs). The current study makes a theoretical contribution by emphasizing the role of moral obligation in moderating the relationship between non-economic factors and tax evasion among SMEs.
\end{abstract}

Keywords Tax Evasion, Peer Influence, Tax Fairness, Tax Complexity, Moral Obligation

\section{Introduction}

Taxes have contributed in countries' economic growth because they allow governments to achieve goals like defense, education, justice, and social welfare for their citizens, while also providing a significant source of revenue to fund growth plans. In this regard, a country's economic development and growth are typically determined by the amount of revenue collected [1]. Taxation has long been employed by governments among most developed and emerging nations to raise cash for economic and non-economic activities, as well as to make government operations more efficient [2]. The significance of taxes for the economy cannot be overstated, as taxes provide the government with revenues [3]. The governments employ the tax system as a fiscal tool (i.e., tax) to improve national economy and attract investment in successful economic prospects. The governments also employ the tax system to control the circulation of particular goods and products throughout the economy in addition to redistributing income [4]. Accordingly, taxation is, without a doubt, one of the main factors that contribute to revenues in a country, as a result, various studies have indicated that avoidance of taxes is a worldwide phenomenon that has resulted in substantial revenue loss [5] particularly in developing countries [6]. Tax evasion is when people engage in illegal and purposeful behaviour in order to reduce their tax liabilities, that it is generally considered a modern financial crime [7]. 
In the case of developing countries, the government is challenged with decreasing tax revenues, which has a detrimental impact on the government's abilities to finance rapidly rising public expenditures [8]. The loss of tax revenues, for example in Jordan as a developing country, was estimated to be about JOD 1387.2 million in 2014 and in 2015, it increased to JOD 1578.2 million[9]. Several researches have been undertaken around the world to investigate the factors influencing tax evasion, with a focus on the developed countries and some on developing countries [10]. However, studies on Middle Eastern countries are quite scarce. Therefore, the factors that contribute to tax evasion are not exhaustive [10]. According to Social Psychological Theories, peer influence, tax fairness and tax complexity have an influence on the effectiveness of the taxation system. However, prior studies on tax evasion are extremely limited. Thus, it is essential to investigate the combined in influences of peer influence, tax fairness and tax complexity on tax evasion. Based on the above-mentioned discussion, this paper provides a conceptual framework for examining the impact of peer influence, tax fairness, and tax complexity on tax evasion.

This paper includes four sections; following this introductory section is section 2 , the review of literature as well as development of the hypothesis which presents the literature about tax evasion, Social Psychological Theories, peer influence, tax fairness, tax complexity and moral obligation as a moderator, followed by section 3 , which includes proposed conceptual framework. Then, the last section involves the conclusion of the study.

\section{Review of Literature and Hypothesis Development}

\subsection{Tax Evasion}

Tax administrations play a fundamental role in curbing tax evasion among taxpayers. However, in spite of the laws and regulations, some taxpayers are still non-compliant. Tax evasion behavior is described as deliberate and illegal activities conducted by organizations or people with the objective of decreasing or entirely ignoring their tax payments [11].

According to Alm [12], tax evasion is an illicit method of prevarication or underpayment utilized by taxpayers to decrease or escape their legally due tax obligations. Sandmo [13] defined tax evasion as a contravention of tax law in which a taxpayer fails to report income that is taxable in theory. Tax evasion is defined as hiding the true value of a legal transaction in order to eliminate or prevent tax liabilities [14]. Furthermore, tax evasion happens when individuals or firms intentionally fail to declare their true revenue in order to conceal activities that should be taxable [15]. The current study focused on tax evasion against tax noncompliance because tax evasion is a severe problem in Middle East countries and at a high level based on some prior reviews $[8,14]$. In this study, tax evasion is related to evading activities involving the use of underreporting sales tax, failing to file tax returns correctly, concealing, misrepresenting, and being to cheating and fraud in tax invoice details to pay very little sales tax [16].

In general, tax evasion problem has been regarded as a severe concern [6]. But the literature specified that the studies_of tax evasion and noncompliance are very limited. Generally, in developing countries, particularly, the studies of tax evasion did not consider the magnitude role of SMEs in the economy of the countries. This study is based on tax evasion literatures. The next section presents the social psychological theories and the determinants factors of tax evasion.

\subsection{Social Psychological Theories}

This research is focused on psychological and social issues in an attempt to discuss the subject of tax evasion from several viewpoints. Andreoni, et al. [17] emphasized the significance of psychological and social theories that are strongly connected to tax evasion in one of the most extensive tax evasion theoretical reviews. In accordance with submissions of Jackson and Milliron [18], Alm [19], and Devos [20] that tax evasion is beyond the explanation of the economic theory alone, the related theories from sociology and psychology have been incorporated to explain the non-economic factors affecting tax evasion. Sociologists and psychologists are concerned in factors such as social influence and attitudes. Regarding the social influence theory, Kelman [21] and Bandura and Walters [22] developed the social influence theory which was proposed by[21], beliefs, individual's attitudes, and subsequent actions or behaviors are the basic theme of social influence theory, and affected by referent others through three processes: namely: 1) Compliance is when people appear to agree with others but keep their opposing viewpoints to themselves; 2) Identification is when people are influenced by people they like and respect, like a well-known person; and 3) Internalization is when people accept a behaviour or a belief and agree both privately and publicly. When it came to issues of fairness perceptions in the workplace, Adams [23] proposed equity theory for the first time. In equity theory, the social-psychology methodology is adopted. In keeping with the equity argument, Adams [23] asserts that when a tax system is perceived to be complicated, people may question its fairness. Furthermore, when the tax system is overly complicated, people may view the entire system as unfair [24].

In this regard, moral development theory can be highlighted. Kohlberg [25] refined and modified prior work by Jean Piaget (1932) to produce a theory on how to establish moral reasoning, which is one of the most 
well-known ideas investigating some of these key concerns. Kohlberg [26] developed Piaget's theory by proposing that moral development is a lifelong process. His theory divides moral development into six stages, each of which is divided into three levels. In essence, Kohlberg [26] agreed with Piaget's (1932) theory of moral development, but he wanted to expand on it. The general organizational structural principles or thinking patterns are emphasized in the moral development hypothesis

\subsection{Peer Influence and Tax Evasion}

Family members, colleagues, friends, significant others, and business acquaintances are all examples of peer influence [27]. Similarly, Bobek, et al. [28] defined peer influence as pressure from close people (e.g., friends, family, business peer, and partner) who have an impact on individual decision-making. Also, it can be defined as an individual's decision to agree or disagree based on their assessment of others' actions in a certain situation [29].

The behaviour of taxpayers is affected by their neighbours' behaviour, or about whom they may have information, or those about whom they may know, or with whom they may engage on a regular basis. Peers have an effect on their counterparts' tax obligation behaviour in SMEs, and SMEs will avoid tax payment if they discover that their peers are evading with consequence [30]. Peer influence is defined by Abd Obaida et al. [31] as the impact of persons who are important to SMEs' owner-managers on their tax compliance decisions, therefore contributing to influencing their attitude toward tax compliance.

Numerous previous studies discovered that peer influence has a major effect on the compliance decisions' determination [28]. Also, past studies have revealed a significantly and positively relation between tax evasion $[32,33]$. In the same line, Daniel and Wong [34] pointed out that taxpayers accept tax evasion if their peers are perceived so. Some other studies reported a significant and negative relationship between peer influence and tax evasion $[35,36]$. While a few other studies pointed out that peer influence has insignificant relation with tax evasion [37, 38].

Some prior studies have indicated that peer influence has a positive relationship with tax evasion $[32,39]$. On the other hand, some studies have demonstrated a negative relationship between peer influence and tax evasion [35, 36]. According to certain research, peer influence has a negligible relationship with evasion $[37,38]$.

According to the preceding discussion, while some earlier literature has shown that peer influence is positively associated with tax evasion, few previous studies have demonstrated either an inconsequential or a negative relationship between peer influence and tax evasion. Based on the preceding discussion as well as relying on socio-psychological theories, the present study hypothesis that is a positive relationship between peer influence and tax evasion.

\subsection{Tax Fairness and Tax Evasion}

Generally, Fairness is described as a viewpoint, a mental image that incorporates a judgement based on a comparison of one's own or others' situations [40]. Fairness of the tax system is one of the fundamental factors for a better tax structure, according to scholars like Thomas [40]. This is a non-economic determinant factor of tax evasion and a critical aspect of taxpayer behaviour[41]. Many taxpayers' decisions on tax compliance appear to be influenced by social motivation, as well as justice. [42]. Thus, fairness perceptions may constitute a vital effect on corporate harmony [43], and more so, for mitigating tax evasion and for motivating taxpayers' compliance [44].

Some taxpayers engage in tax evasion, while others, because of their high level of awareness of the need to fulfil tax duties, continue to pay their taxes. The burden on taxpayers will be enhanced when the government implements the tax hike because of the new tax, therefore, encouraging them to participate in tax evasion acts [6]. In sum, to the researcher's knowledge, limited studies are available that examined tax fairness in indirect taxes.

Tax fairness is a non-economic aspect that affects taxpayers' attitudes and views of the tax system's fairness, which influences tax evasion and is a key factor in the decision-making of taxpayer [41]. This was explained by the equity theory, which proposed that the fairness of the tax system has a favorable impact on taxpayer behaviour[41]. The majority of prior studies that focused on tax evasion and tax fairness yielded conflicting results. According to Slehat [45], tax fairness has a positive and significant relationship with tax evasion. Many previous studies on tax evasion, on the other hand, have indicated a strong negative relationship between tax fairness and tax evasion behavior $[35,46]$. Tax fairness is also strongly and negatively associated with tax evasion, according to Hite and Roberts [47]. Previous research, on the other hand, has found no substantial link between tax fairness and tax evasion [48, 49]. The most fundamental variables leading to tax evasion behaviour are the fairness of the tax system (in terms of its application and rates) and proper tax revenue spending. To significantly make things better, taxpayers must believe that the taxing authority is legitimate, that the tax system is fair, and that government expenditure is helpful and efficient [5]. Given the foregoing examination of the direct relationship between tax fairness and tax evasion, and based on socio-psychological theories is negative. Therefore, the current study proposes that tax fairness negatively related to tax evasion.

\subsection{Tax Complexity and Tax Evasion}

Tax complexity is a property of the tax system that stems from the challenge of reading, interpreting, and 
inefficiencies in the tax framework, as well as complying with the tax code [50]. According to recent studies, tax complexity has risen dramatically in recent years [51]. At least two variables can be blamed for the rise. The first is the implementation and adaptation of tax measures to guarantee a level playing field for businesses and address tax loopholes, which will result in significant costs and uncertainties. The second is the development of tax incentives and systems to attract investments in order to reduce costs and provide opportunities for tax planning [51]. According to Faridy et al. [52], there are three kinds of tax complexity that are deeply embedded in many tax systems: compliance complexity, structural complexity, and technical complexity. Furthermore, Chau and Leung [53] noted that complexity has two dimensions in terms of tax compliance behavior, namely, a lot of complicated math in estimating tax owing and a lot of intricacies in tax legislation. As a result, this emphasizes the need of having a thorough understanding of the tax system and reducing tax complexity [54].

The complexity of the tax structure has a significant impact on tax evasion [55]. Cox and Eger [56] concentrated on the Kentucky State Road Funds in the United States. They discovered that procedural tax complexity leads to an additional tax evasion; conversely, lowering the complexity of taxation policies and legislation may deter tax evasion. Saad [57] and some other previous empirical investigations, found that tax complexity is linked to tax evasion and that complexity is a significant determinant in evasion behaviour among company income taxpayers. Tax complexity is thought to be the most important factor of tax evasion [58]. A favorable association between tax complexity and tax evasion has been found in many prior studies on tax evasion [33, 54, 58]. Similarly, Pope [50] claimed that simplifying tax rules and procedures is one of the most effective strategies to reduce tax non-compliance among taxpayers. Furthermore, Loo, et al. [59] pointed out that when tax regulations are complex, people may find them difficult to comprehend, resulting in non-compliance. Conversely, few prior previous researches have discovered that tax complexity negatively related to tax evasion [60]. On the contrary, Faridy, et al. [52] stated that tax complexity insignificantly correlated with tax evasion. According to the above discussions on the related studies and the direct relationship of tax complexity, and also based on the socio-psychological theories, the majority of studies agree that the relationship between tax complexity and tax evasion is positive. Therefore, the present study suggests that tax complexity positively related to tax evasion.

\subsection{Moral Obligation as a Moderator}

When the association between independent and dependent variables is extremely weak, inconsistent, or even no relationship at all, a moderating variable is included to decrease or increase the relationship
[61].Moral obligation is the individual's internalization of positive behavior norms, which mostly influence individual behavior by interior constraints [62]. According to [62], moral obligation is defined as "an individual's internalized ethical rules, which reflect their personal beliefs about right and wrong". It is essentially of how an individual personally senses responsibility towards others. Milesi and Alberici [63] stated that the moral obligation of individuals should motivate their commitment to engage in compliance with their conscience, regardless of how much it could cost or whether it is likely to be successful. Moral obligation is internal motivation of an individual's good behavioral norms, which mainly influence personal behaviour by internal constraints [62]. Hence, having a moral obligation entails acting against one's own self-interest and considering others while taking a stand; it also refers to people's positive attitudes that help the community, even if it may cause personal cost and lead to reduce one's personal benefit [64].

Milesi and Alberici [63] indicated that among the internal forces, moral obligation is a significant factor. It is part of the worth appraisal system internalized by individuals [65]. And it is usually defined as a "personal decision to participate in a specific collective action based on the belief that this is what should be done" [62]. Due to a person's thoughtfulness about wrong and right, the moral obligation becomes a high responsibility. Previous analysis has demonstrated the significance of this variable and some models have paid less attention to it because very few attempts have been made to change actions and motives only by focusing on TRA \& TPB [66]. Regarding taxation context, moral is considered as the intrinsic motivation or internalized willingness to comply paying taxes [67]. This is in line with Young, et al. [68] study who defined moral behavior as an intrinsic motivation provided by ethical and moral values. Moral obligation is supposed to be among the important forces to broaden tax compliance behavior understanding.

Generally, the moral obligation may clarify why some individuals do not evade. Torgler, et al. [69] argued that when morale is high, tax compliance is pretty high as well. As a result, moral obligation is critical for tax compliance and is a key factor in defining the extent of tax evasion as well as the shadow economy. However, moral principles related positively to tax compliance [70]. As for tax evasion is often a negative behavior, moral obligation is considered to be significant in and of itself, regardless of its impact on an individual's attitudes. [71].

Some also have proposed that moral obligation to pay taxes sometimes may differ systematically, throughout countries, for reasons relating primarily to tax authorities and enforcement but also to such factors as cultural norms [72]. Morals may be among the key and significant factors of tax evasion and other sorts of behavior if taxpayer values are influenced by cultural norms, with various societal institutions functioning as restrictions and varying from nation to another, however, it is notoriously difficult to 
isolate the reasons for those differences in moral[72] .

Moral obligation, which is growing in importance in an individual's mind, leads to eager compliance with the country's tax regulations [32]. The moral obligation variable has a significant impact on tax compliance behaviour, as it determines which taxpayers comply with tax regulations because they believe they have a moral need to do so. In conclusion, moral obligation should influence compliance intentions, but it may also interact with the effects of other factors. Edwards and Lambert [73] argued that in studies involving individual differences or social situations, a moderator variable is used to evaluate if it weakens or strengthens the link between the independent and the dependent variables. The moral obligation has been proposed as a moderating factor.

Moral obligation is increasingly being used in socio-psychological theories to determine the amount of tax evasion. This research demonstrates that moral obligation may have a moderating effect on the favourable association between peer influence and tax evasion behaviour. Since tax system is notorious for high levels of tax evasion [5]. Also, the literature emphasized the need for alternative approaches for more understanding of the sophisticated behavior of tax evasion and the incorporation of the social norms [69]. When two variables have an inconsistent relationship, a moderating variable is introduced, according to Baron and Kenny [61]. Tax evasion is expected to be minimal when taxpayers' moral obligations are high. This means that in the presence of the moderating effect of moral obligation, the positive association between peer influence, tax complexity, and tax evasion behaviour will be decreased. Based on earlier considerations of the moral obligation's moderating effect, it is possible that the original association between peer influence and tax evasion will be weakened. Furthermore, moral obligation has the potential to deepen the link between tax justice and tax evasion. Even though the tax system is unfair, people who have a strong moral commitment can adhere to it. As a result, taxpayer views of justice will help to reduce tax evasion. Based on the previous explanation of moral obligation's moderating influence and socio psychology theories, this study hypothesized that moral obligation weakens the positive relationship between peer influence, tax complexity, and tax evasion. On the other hand, moral obligation strengthens the negative relationship between tax fairness and tax evasion

\section{Proposed Conceptual Framework}

In summary, the proposed conceptual framework of this research is established and supported by the integration of Social Psychological Theories, implying that peer influence, tax justice, and tax complexity impact tax behaviour. The current study examines the moderating effect of moral obligation on the relationship between peer influence, tax complexity, tax fairness, and tax evasion among SMEs. The model is based on Social Psychological Theories, and it proposes that tax evasion behaviour is influenced by tax complexity, perceived tax fairness, and peer influence. The Social Influence Theory [22] focuses on how other people influence an individual's feelings, opinions, or conduct. The theory of social influence is tied to Bandura's [22] Social Learning Theory, which states that an individual is impacted by their surroundings. [21] defined social influence as the way in which an individual's thoughts, behavior, and feelings are influenced by the impact of others. As a result, investigating moral obligation as a moderating component may be beneficial to blend findings. As a result, this study suggests the following conceptual framework, as illustrated in Figure 1 below, based on the prior talks.

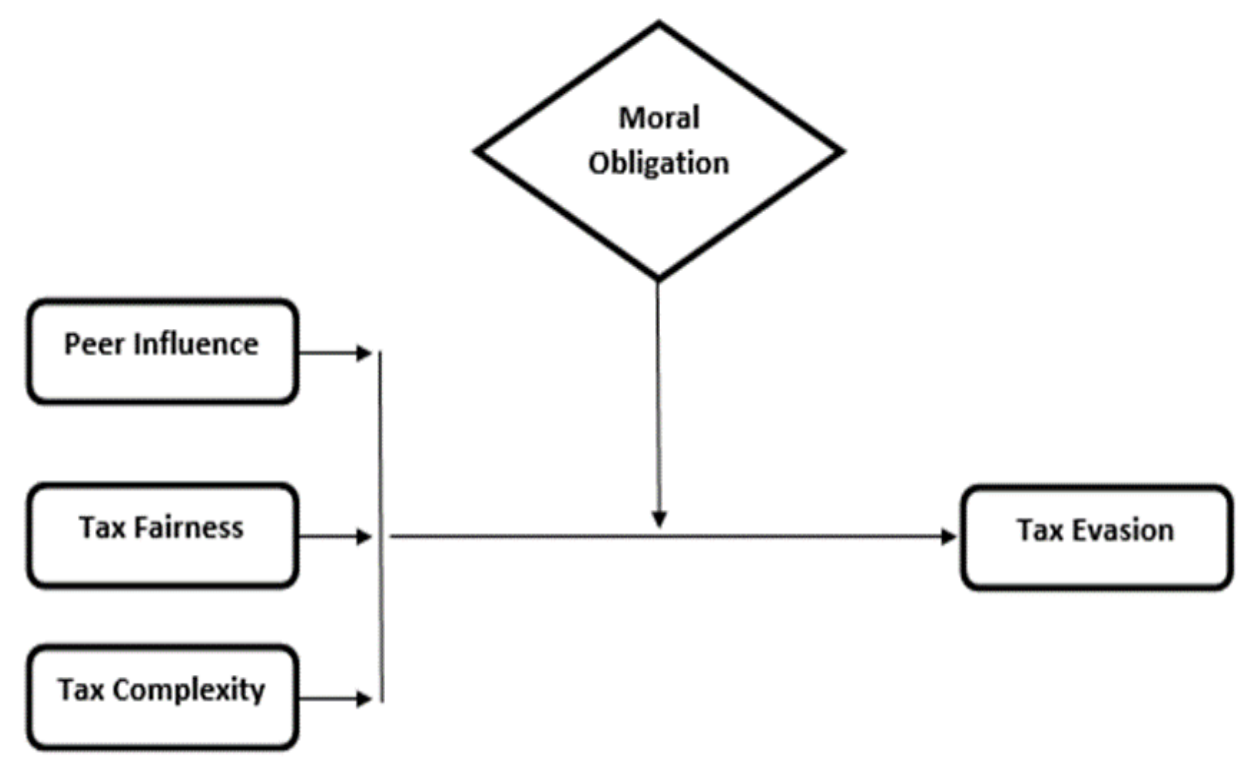

Figure 1. The Proposed Conceptual Research Framework 


\section{Conclusions}

It is evident that tax evasion has become a challenge for the world's stakeholder. Therefore, a thorough understanding of the determinant's factors affecting tax evasion cannot be underestimated. Three factors, namely peer influence, tax fairness and tax complexity have been identified as the most empirically tested determinants factors of tax evasion. Due to its nature and frequent changes in rules, tax laws, regulations and requirements, tax transparency appears to attract the attention of recent researchers. Therefore, there is a vigorous need for continuous research on this area throughout time, as it presents challenging research opportunities to both tax administrators and scholars. At short, this is based on previous studies on the tax evasion determinants that are foremost derived from the non-economic perspective and subsequently proposes future studies to integrate tax transparency and political factors in tax evasion model. Furthermore, the composition of research on tax compliance indicated that the literature on tax evasion which included both analytical and empirical studies mainly focused on developed countries. However, few studies in the Middle East region on tax evasion have been conducted. As a result, it is convenient to pay more attention to developing countries like Jordan.

\section{REFERENCES}

[1] S. A. Güzela, Ö. Gökhan, and Ö. Murat, "The effect of the variables of tax justice perception and trust in government on tax compliance: The case of Turkey," Journal of Behavioral and Experimental Economics, vol. 78, pp. 80-86, 2019, doi: 10.1016/j.socec.2018.12.006.

[2] P. Sinnasamy and Z. Bidin, "The relationship between tax rate, penalty rate, tax fairness and excise duty non-compliance," in SHS web of conferences, 2017, vol. 34: EDP Sciences.

[3] D. Alsheikh, M. AlAdham, M. Qasem, and A. Yousef, "Factors affecting corporate tax evasion: Evidence from Jordan," International Journal fro Innovation Education and Research, vol. 4, no. 6, pp. 1-16, 2016. [Online]. Available: www.ijier.net.

[4] B. H. Malkawi and H. A. Haloush, "The case of income tax evasion in Jordan: symptoms and solutions," Journal of Financial Crime, vol. 15, no. 3, pp. 282-294, 2008, doi: $10.1108 / 13590790810882874$.

[5] F. Alasfour, "Costs of distrust: The virtuous cycle of tax compliance in Jordan," Journal of Business Ethics, vol. 155, no. 1, pp. 243-258, 2019, doi: 10.1007/s10551-017-3473-y.

[6] M. A. A. AlAdham, M. A. Abukhadijeh, and M. F. Qasem, "Tax evasion and tax awareness evidence from Jordan," International Business Research, vol. 9, no. 12, pp. 65-75, 2016, doi: 10.5539/ibr.v9n12p65.

[7] N. T. Festo, "Tax compliance by the small and medium-sized corporations: A case of uganda," PHD degree doctoral dessirtation, University of Exeter United Kingdom, 2018.

[8] E. a. t. A. Hadidi, "Tax evasion in jordan: Reality, causes and results," Research Journal of Finance and Accounting, vol. 8, no. 12, 2017.

[9] E. Economic and Social Council Jordan, "Tax evasion in Jordan," 2014, doi: http://www.esc.jo/Homeen.aspx.

[10] L. H. A. Al-Ttaffi, "Determinants of tax non-compliance behaviour of Yemeni SMEs: a moderating role of Islamic religious perspective," Unpublished doctoral dissertation, Universiti Utara Malaysia, Malaysia, 2017.

[11] J. Alm, Y. Liu, and K. Zhang, "Financial constraints and firm tax evasion," International Tax and Public Finance, vol. 26, no. 1, pp. 71-102, 2019, doi: 10.1007/s10797-0.

[12] J. Alm, "Measuring, explaining, and controlling tax evasion: lessons from theory, experiments, and field studies," International tax and public finance, vol. 19, no. 1, pp. 54-77, 2012.

[13] A. Sandmo, "The theory of tax evasion: A retrospective view," National tax journal, pp. 643-663, 2005.

[14] S. Y. Al-Freijat and M. K. Adeinat, "Determinants of tax effort and tax capacity in jordan during the period (2000-2017)," International Journal of Business and Economics Research, vol. 9, no. 1, pp. 1-10, 2020.

[15] F. N. Tusubira, "Tax compliance by the small and medium-sized corporations: A case of uganda," 2018.

[16] N. Koumbiadis, J. O. Okpara, G. M. Pandit, and T. Ritsatos, "Tax evasion and compliance; From the neo classical paradigm to behavioural economics, a review," Journal of Accounting \& Organizational Change, vol. 10, no. 2, pp. 244-262, 2014, doi: 10.1108/JAOC-07-2012-0059.

[17] J. Andreoni, B. Erard, and J. Feinstein, "Tax compliance," Journal of economic literature, vol. 36, no. 2, pp. 818-860, 1998.

[18] B. R. Jackson and V. C. Milliron, "Tax compliance research: Findings, problems, and prospects," Journal of accounting literature, vol. 5, no. 1, pp. 125-165, 1986.

[19] J. Alm, "Tax compliance and administration," Public Administration and Public Policy, vol. 72, pp. 741-768, 1999. [Online]. Available:https://www.researchgate.net/pu blication/247699437.

[20] K. Devos, "Measuring and analysing deterrence in taxpayer compliance research," J. Austl. Tax'n, vol. 10, p. 182, 2007.

[21] H. C. Kelman, "Further thoughts on the process of compliance, Identification, and Internalaization," in Social Power and Political Influence, J. T. Tedeschi Ed. USA, 1974.

[22] A. Bandura and R. H. Walters, Social learning theory. United States of America, Stanford University: Prentice-hall Englewood Cliffs, NJ, 1977, p. 46.

[23] J. S. Adams, "Inequity in social exchange," in Advances in experimental social psychology, vol. 2: Elsevier, 1965, pp. 267-299.

[24] O.-H. Fjeldstad, I. H. Sjursen, and M. Ali, "Factors 
affecting tax compliant attitude in Africa: Evidence from Kenya, Tanzania, Uganda and South Africa," 2013.

[25] L. Kohlberg, "Stage and sequence: The cognitive development approach to socialization," Handbook of socialization theory and research, pp. 345-480, 1969.

[26] L. Kohlberg and R. H. Hersh, "Moral development: A review of the theory," Theory into practice, vol. 16, no. 2, pp. 53-59, 1977.

[27] M. Tilahun, "Determinants of tax compliance: A systematic review," Economics, vol. 8, no. 1, pp. 1-7, 2019.

[28] D. D. Bobek, A. M. Hageman, and C. F. Kelliher, "Analyzing the role of social norms in tax compliance behavior," Journal of Business Ethics, vol. 115, no. 3, pp. 451-468, 2013, doi: 10.1007/s10551-012-1390-7.

[29] O. s. Denise Bowen, "Tax compliance determinants: A proposed model for cross-country analysis," PHD degree doctorl dissertation, University of Texas, Texas, USA, 2014.

[30] N. Maseko, "The impact of personal tax knowledge and compliance costs on tax compliance behaviour of SMEs in Zimbabwe," Elite Research Journal of Accounting and Business Management, vol. 2, no. 3, pp. 26-37, 2014.

[31] M. M. Abd Obaida, I. Ibrahimb, and N. M. Udinc, "The moderating role of subsidy removal on factors influencing SMEs tax compliance in yemen," International Journal of Innovation, Creativity and Change, vol. 11, no. 10, pp. 316-338, 2020

[32] Z. M. Bhutta, R. Rasheed, and A. B. Khan, "Psychological factors affecting tax compliance behavior of pakistani tax payer: An extended theory of planned behavior perspective," Pakistan Journal of Social Sciences (PJSS), vol. 39, no. 4, 2019. [Online]. Available: https://www.bzu.edu.pk/PJSS/Vol39No4/PJSS-Vol39-No4 $-23 . p d f$.

[33] G. Richardson, "Determinants of tax evasion: A cross-country investigation," Journal of international Accounting, Auditing and taxation, vol. 15, no. 2, pp. 150-169, 2006

[34] H. Daniel and B. Wong, "Issues on compliance and ethics in taxation: what do we know?," Journal of Financial Crime, vol. 15, no. 4, pp. 369-382, 2008, doi: 10.1108/13590790810907218.

[35] A. A. Alkhatib, H. Abdul-Jabbar, F. Abuamria, and A. Rahhal, "The effects of social influence factors on income tax evasion among the palestinian smes," International Journal of Advanced Science and Technology, vol. 28, no. 17, pp. 690-700, 2019. [Online]. Available: https://www.researchgate.net/publication/338229230.

[36] P. Alleyne and T. Harris, "Antecedents of taxpayers' intentions to engage in tax evasion: evidence from Barbados," Journal of Financial Reporting and Accounting, vol. 15, no. 1, pp. 2-21, 2017, doi: 10.1108/JFRA-12-2015-0107.

[37] C. Blanthorne and S. Kaplan, "An egocentric model of the relations among the opportunity to underreport, social norms, ethical beliefs, and underreporting behavior," Accounting, Organizations and Society, vol. 33, no. 7-8, pp. 684-703, 2008
[38] D. M. Hanno and G. R. Violette, "An analysis of moral and social influences on taxpayer behavior," Behavioral research in Accounting, vol. 8, pp. 57-75, 1996.

[39] L. Abdixhiku, G. Pugh, and I. Hashi, "Business tax evasion in transition economies: a cross-country panel investigation," The European Journal of Comparative Economics, vol. 15, no. 1, pp. 11-36, 2018, doi: http://dx.doi.org/10.25428/1824-2979/201801-11-36.

[40] C. Thomas, "Assessing tax fairness dimensions in a small developing economy," Business and Economics Journal, 2012.

[41] J. Farrar, S. E. Kaplan, and L. Thorne, "The effect of interactional fairness and detection on taxpayers' compliance intentions," Journal of Business Ethics, vol. 154, no. 1, pp. 167-180, 2017.

[42] A. Antoci, P. Russu, and L. Zarri, "Tax evasion in a behaviorally heterogeneous society: An evolutionary analysis," Economic Modelling, vol. 42, pp. 106-115, 2014.

[43] M. E. Schweitzer and D. E. Gibson, "Fairness, feelings, and ethical decision-making: Consequences of violating community standards of fairness," Journal of Business Ethics, vol. 77, no. 3, pp. 287-301, 2008.

[44] T. Hartner, Martina, B. Kubicek, E. Kirchler, S. Rechberger, and M. Wenzel, "Perceived distributive fairness of European transfer payments and EU - taxes in Austria, the Czech Republic, and the United Kingdom," Applied psychology, vol. 61, no. 3, pp. 454-478, 2012.

[45] Y. A. A. A. Slehat, "The Tendency Toward Tax Evasion in Jordan," Unpublished master's thesis, Universiti Utara Malaysia, Malaysia, 2009.

[46] D. Jemberie and Birhanie, "Investigations of determinants for tax evasion in category'c'taxpayers: A case of adet town," CLEAR International Journal of Research in Commerce \& Management, vol. 11, no. 1, 2020.

[47] P. Hite and M. Roberts, "Analysis of the tax reform based on taxpayers perceptions of fairness and self-interest. 'Advanced in Taxation'," Advances in taxation : a research annual., vol. 4, pp. 115-137, 1992

[48] S. M. Faizal and M. R. Palil, "Study on fairness and individual tax compliance in Malaysia: Preliminary findings," International Journal of Business, Economics and Law, vol. 8, no. 1, pp. 74-79, 2015.

[49] N. Saad, "Fairness perceptions and compliance behaviour: The case of salaried taxpayers in Malaysia after implementation of the self-assessment system," eJTR, vol. 8, p. 32,2010

[50] T. Hoppe, D. Schanz, S. Sturm, and C. Sureth-Sloane. "2016 Global MNC Tax Complexity Survey." https://www.taxcomplexity.org/ (accessed.

[51] T. Hoppe, D. Schanz, S. Sturm, and C. Sureth-Sloane. "Measuring tax complexity across countries: A survey study on MNCs, (discussion paper, No. 245)." https://www.econstor.eu/bitstream/10419/204651/1/16790 97326.pdf

[52] N. Faridy, R. Copp, B. Freudenberg, and T. Sarker, "Complexity, compliance costs and non-compliance with vat by small and medium enterprises in bangladesh: Is there a relationship," Austl. Tax F., vol. 29, p. 281, 2014. 
[53] G. Chau and P. Leung, "A critical review of Fischer tax compliance model: A research synthesis," Journal of accounting and taxation, vol. 1, no. 2, pp. 34-40, 2009. [Online].

Available: http://ira.lib.polyu.edu.hk/bitstream/10397/5823/1/Chau_cr itical_review_Fischer.pdf.

[54] A. Al-Mamun, H. Entebang, S. A. Mansor, Q. R. Yasser, T. M. Nathan, and M. Rahman, "The impact of demographic factors on tax compliance attitude and behavior in malaysia," Journal of Finance, Accounting \& Management, vol. 5, no. 1, 2014.

[55] T. O. Muhrtala and M. Ogundeji, "Professionals' perspective of tax evasion: some evidence from Nigeria," Europe, vol. 18, no. 20.50, pp. 1,511,714, 2013.

[56] S. P. Cox and R. J. Eger "Procedural complexity of tax administration: The road fund case," Journal of Public Budgeting, Accounting \& Financial Management, vol. 18, no. 3, p. 259, 2006.

[57] N. Saad, "Tax Non-Compliance Behaviour: Taxpayers View," Procedia-Social and Behavioral Sciences, vol. 65, pp. 344-351, 2012.

[58] M. R. Palil, M. M. Malek, and A. R. Jaguli, "Issues, challenges and problems with tax evasion: The institutional factors approach," Gadjah Mada International Journal of Business, vol. 18, no. 2, pp. 187-206, 2016.

[59] E. C. Loo, M. McKerchar, and A. Hansford, "Findings on the impact of self assessment on the compliance behaviour of individual taxpayers in Malaysia: A case study approach," J. Austl. Tax'n, vol. 13, p. 1, 2010.

[60] E. Christie and M. Holzner. "What Explains Tax Evasion? An Empirical Assessment based on European Data, wiiw Working Paper, No. 40, The Vienna Institute for International Economic Studies (wiiw), ." WIIW Working Paper.

https://www.econstor.eu/bitstream/10419/203905/1/wiiwwp-040.pdf (accessed.

[61] R. M. Baron and D. A. Kenny, "The moderator-mediator variable distinction in social psychological research: Conceptual, strategic, and statistical considerations," Journal of personality and social psychology, vol. 51, no. 6, p. 1173, 1986. [Online]. Available: http://webcom.upmf-gr enoble.fr/LIP/Perso/DMuller/GSERM/Articles/Journal $\% 2$ 0of $\% 20$ Personality $\% 20$ and $\% 20$ Social $\% 20$ Psychology $\% 20$ 1986\%20Baron.pdf.

[62] J.-M. Sabucedo, M. Dono, M. Alzate, and G. Seoane, "The importance of protesters' morals: moral obligation as a key variable to understand collective action," Frontiers in psychology, vol. 9, p. 418, 2018.

[63] P. Milesi and A. I. Alberici, "Pluralistic morality and collective action: The role of moral foundations," Group Processes \& Intergroup Relations, vol. 21, no. 2, pp. 235-256, 2018.

[64] L. Andriani, "Tax morale and prosocial behaviour: evidence from a Palestinian survey," Cambridge Journal of Economics, vol. 40, no. 3, pp. 821-841, 2015. [Online]. Available: http://eprints.bbk.ac.uk/12020/.

[65] M. Yazdanpanah and M. Forouzani, "Application of the theory of planned behaviour to predict iranian students' intention to purchase organic food," Journal of Cleaner Production, vol. 107, pp. 342-352, 2015.

[66] L. Beck and I. Ajzen, "Predicting dishonest actions using the theory of planned behavior," Journal of research in personality, vol. 25, no. 3, pp. 285-301, 1991, doi: 10.1016/0092-6566(91)90021-H.

[67] M. Hosseini Kondelaji, M. Sameti, H. Amiri, and R. Moayedfar, "Analyzing determinants of tax morale based on social psychology theory: case study of Iran," Iranian Economic Review, vol. 20, no. 4, pp. 581-598, 2016.

[68] A. Young, L. Lei, B. Wong, and B. Kwok, "Individual tax compliance in China: a review," International Journal of Law and management, 2016.

[69] B. Torgler, M. Schaffner, and A. Macintyre, "Tax compliance, tax compliance, tax morale, and governance quality," International Studies Program Working Paper, vol. 727, 2007.

[70] T. B. AL-Shawawreh and B. Y. AL-Smirat, "Economic effects of tax evasion on jordanian economy," International Journal of Economics and Finance, vol. 8, no. 7, pp. 344-348, 2016

[71] D. D. Bobek and R. C. Hatfield, "An investigation of the theory of planned behavior and the role of moral obligation in tax compliance," Behavioral Research in Accounting, vol. 15, no. 1, pp. 13-38, 2003, doi: 10.2308/bria.2003.15.1.13.

[72] B. Torgler, "Tax morale in latin america," Public Choice, vol. 122, no. 1-2, pp. 133-157, 2005.

[73] J. R. Edwards and L. S. Lambert, "Methods for integrating moderation and mediation: a general analytical framework using moderated path analysis," Psychological methods, vol. 12, no. 1, p. 1, 2007. 